\title{
Roughing up smooth brome and dethroning crested wheatgrass with native plants: dominant to subordinate on Utah rangeland
}

\author{
Val Jo Anderson and Robert L Johnson
}

ABSTRACT

The vast plantings of smooth brome (Bromus inermis Leyss. [Poaceae]) and crested wheatgrass (Agropyron cristatum (L.) Gaertn. [Poaceae]) throughout the Intermountain West have come under scrutiny for their lack of native plant diversity. We looked at the results of 2 projects that were intended to introduce native plant diversity into monocultures of smooth brome and crested wheatgrass in central and western Utah 20 y ago. Results immediately following the crested wheatgrass planting were impressive, though subsequently the native plants became largely extirpated. The initial results following the smooth brome planting were dismal, but decades later a diverse native plant community had developed. Under the pressures of historic overgrazing, soil erosion, climate change, weed invasion, and frequent fire, a reasonable question is whether restoration of disturbed sites can approximate pre-European settlement plant communities. Significant work on native species plant material development and seed transfer zones have at their core sentiment the return to native communities. The case studies in this article, while limited in scope, indicate that early plantings of well-adapted introduced grasses have become naturalized to these systems and can be temporarily displaced but not removed. They provide important elements of functional stability but are limited in the attributes associated with more diverse native plant communities. A model of augmentation that inserts competitive native plants into established introduced grass stands has the best chance of achieving the combination of site stability with other ecosystem services. The longevity and resilience of the native plant augmentations, however, remain uncertain under continuing and developing perturbations.

Anderson VJ, Johnson RL. 2020. Roughing up smooth brome and dethroning crested wheatgrass with native plants: dominant to subordinate on Utah rangeland. Native Plants Journal 21(3):281-289.

This open access article is distributed under the terms of the CC-BY-NC-ND license (http://creativecommons. org/licenses/byncnd/4.0) and is freely available online at: http://npj.uwpress.org.

\section{KEY WORDS}

restoration, crested wheatgrass, cheatgrass, diversity, stability, land management, Poaceae

\section{NOMENCLATURE}

Tropicos.org, Missouri Botanical Garden (2020)

Photos by the authors 
$\mathrm{T}$ he settlement of the Intermountain West during the last half of the 19th century brought significantly new and increased demands of the land. These uses changed landscapes, ecosystems, and plant and animal communities. Loss of plants and soil modified the land's potential to produce the kind and amount of plants and animals of which it was once capable. The best land was converted from wild ecosystems to croplands by early settlers. Their perceptions of the remaining land to be used as a grazing resource is represented by an excerpt taken from an 1849 letter of Parley P Pratt (Mormon Church leader and early Utah settler) to his brother Orson, in which he is describing grazing opportunities in newly settled Utah:

As a grazing country, there is scarce its equal on the globe. Milk, cheese, butter, beef, \&c., are very fine and abundant. The region around us would support millions of cattle and sheep, not only in the vallies but on the mountains. Our cattle climb the highest hills, and delight to graze on the sides of the steepest declivities where it is possible for them to climb. (Pratt 1849)

This statement was prophetic, as by 1900 more than 2.5 million sheep and 400,000 cattle grazed Utah lands (Johnson 1989). This trend was apparent throughout the 17 western states as cattle numbers soared from 4.6 million in 1870 to nearly 40 million by the mid-1880s (Holechek and others 2004), and sheep numbers increased from 4.7 million in 1870 to nearly 25 million by 1910 (Connor 1921).

The primary vector of wildland degradation was unregulated overgrazing by domestic livestock, which resulted in altered plant communities and extensive erosion. Later, 2 additional vectors of change, 1) control of naturally occurring wildfires and 2) the introduction and subsequent invasion of these lands by aggressive weedy plant species, compounded the problems caused by overgrazing. By the turn of the 20th century, both local and national attention was focused on the massive flooding and mudslides happening throughout the West, especially in areas and communities adjacent to the steep slopes of western mountain ranges. Urgent requests were made to the secretary of agriculture, which set in motion the 1912 creation of the Great Basin Experiment Station set in Ephraim Canyon, Utah, an area of the West plagued by frequent and massive summer floods and mud flows (Keck 1972).

Arthur W Sampson was named station director and was given the charge to determine the cause of the summertime flooding and to find solutions to this and other range-related problems. He quickly concluded that overgrazing on the high mountain watersheds was the primary cause of flooding. Many experiments by this group (1912) and others across the western US focused on revegetating grazing-disturbed and decimated rangelands. These studies included the evaluation of both na- tive and introduced plant species. The goal was to find plants that could be successfully established on degraded sites to hold the areas from further erosion, but that could also provide a more grazing-resistant forage resource for the productionminded society of the time. Smooth brome (Bromus inermis Leyss. [Poaceae]) was a very common species in these trials and was uniformly successful and subsequently widely seeded. In drier zones, an analogous species, crested wheatgrass (Agropyron cristatum (L.) Gaertn. [Poaceae]), was similarly successful in trials and subsequently planted across millions of acres of grazing-degraded semi-arid rangelands.

While these species were often seeded in mixes with other species, the comparative aggressive nature of these plants was understood. Pickford and Jackman (1944) recommended using a mixture of species for seeding to reduce the risk of a complete failure and also to create a mixed forage that is preferred by livestock. However, they also recommended not spending money on many species for uniform sites where smooth bromegrass performed well. These grasses, while used very successfully to arrest soil erosion and increase grazing-resistant forage, are now often viewed as alien plant invaders (Larson and others 2001). The intended success of these grasses as viewed by an earlier generation of land stewards has been deemed an invading weed problem for a later generation. Yet, we have millions of acres of land disturbed by grazing, fire, or other perturbations where soil is being lost and weedy annuals force a foreign ecology.

To assess the condition of rangeland, an interagency taskforce was formed to develop a methodology that could be used to determine the health of a unit area at a given point in time. The result was the publication of Interpreting Indicators of Rangeland Health (Pellant and others 2005). Smooth brome- or crested wheat grass-dominated lands will typically score relatively high when a rangeland health assessment (Pellant and others 2005) of the site is made. Of the 17 indicators of rangeland health, only number 12, functional/structural groups, would typically deviate from the expectations of an ecologically functioning site. That being the case, one is left to wonder why we would attack stable, useful, and mostly ecologically healthy rangelands dominated by smooth brome and crested wheatgrass when so much land needs revegetation and restoration attention.

While plant community diversity may be limited in these sites, the soil is safe, forage value is high, and further disturbance may put them at risk once again. Is diversity really that critical or even uniformly desirable? Is it possible to restore diversity on these recovered sites, given current native plant materials and planting technologies? If possible, is it worth the cost? Restoring plant diversity in natural landscapes where that diversity has been negatively impacted is applauded as a noble cause. It ensures natural sustainability for all life forms. Who can reasonably argue that less plant richness and diversity is 
the preferred ecological state? Outside of the altruistic view of species conservation and the frequent politically motivated fulfillment of those views, are there scientifically valid reasons that can justify efforts to restore diversity to depauperate landscapes?

The prevailing idea that has rallied support for community diversity is the diversity-stability theory. This theory asserts that more diverse communities are more stable (less likely to suffer from disruptions). This stability can in part be explained by ecosystem resistance and resilience; that is, its ability to resist perturbation and its speed of recovery. Communities that are species rich are able to express a correlating diversity of traits, which increase the likelihood of the presence of a trait better able to cope with an impending abiotic or biotic stress and likewise influence community recovery. Stress can come from climate variability, disease, fire, herbivory, and so forth, as well as from anthropogenic influences such as grazing, pollution, and invasive species.

The diversity-stability theory gained support through GD Tilman's seminal work in Minnesota grasslands where he was able to demonstrate a positive correlation between species richness and drought resistance as measured by plant biomass (Tilman and Downing 1994). His work strengthened the justification for conservation of biodiversity and that "diversity begets stability." Still, scientists questioned whether the observed positive correlation was attributable to plant diversity or rather functional diversity between multiple life forms. Subsequently, Tilman and colleagues (1997) were able to show that indeed functional diversity had the same positive correlation to plant stability as measured by plant biomass, and that not all plants contribute equally to functional stability. Still, plant diversity might be the simplest way to assess functional diversity, the expectation being that plant diversity links to other organism diversity in the food web that contributes to stability.

To understand functional diversity, we need to define "ecosystem function." De Groot (1992) defined ecosystem function as "the capacity of natural processes and components to provide goods and services that satisfy human need, directly or indirectly." Those goods and services are not limited to primary production, but instead include all ecological processes that sustain or add value to life, such as bio-geochemical processes, genetic and evolutionary processes, nutrient cycling, and cognitive development (De Groot and others 2002). Tilman's (2001) definition of functional diversity as the value and range of species and the traits that contribute to a functional ecosystem suggests that it is the diversity of traits present in the organisms of a given assemblage that influence the functionality of that assemblage or of an ecosystem as described above. Therefore, functional diversity is best measured through measuring functional trait diversity (Petchey and Gaston 2006), not simply organism diversity.
If conserving biodiversity is good and can positively affect stability, which 1) is due primarily to functional diversity, and 2 ) is needed for a functioning ecosystem, it only stands to reason that we should expand our thinking to include ecosystem multifunctionality as an ecological measure. It implies that ecosystems are most accurately described by measuring multiple functions. Because ecosystem functionality can be interpreted in different ways at different scales, multiple scales should be investigated. At the management level, it means "maintaining ecosystem multifunctionality will require diverse landscape mosaics of diverse communities" (Pasari and others 2013). Getting to the bottom of the relationship between biodiversity and functional diversity at multiple scales has blossomed into a web of complexity that cannot easily inform management decisions, whereas the mosaic landscape concept is already intuitively understood by land managers as a desirable model for habitat heterogeneity, which ironically encompasses much of the biotic and functional diversity dilemma.

Early range managers and practitioners were likely unaware of the arguments now made for diversity, and their primary concerns were to stabilize sites relative to erosion and to produce forage. Hence, the practice of reseeding damaged western rangelands with the aggressive and adapted introduced grass species began in the 1920s and continued unabashed through the 1960s on private and public lands alike. This practice extended to semi-arid rangelands where range improvement efforts included burning or anchor-chaining pinyon-juniper or sagebrush sites followed by seeding crested wheatgrass. This approach was especially true if the dominant understory was cheatgrass (Bromus tectorum L. [Poaceae]). More recently as catastrophic fires have burned and reburned vast acres of rangeland, monocultures of cheatgrass have established. Using the highly competitive crested wheatgrass in reseeding has reclaimed sites from a modified ecology formed by monocultures of cheatgrass, bringing sites back to a more native-like temperate bunchgrass ecology.

\section{CASE STUDIES}

Understanding the arguments for diversity and conservation of native species, Cox and Anderson (2004) used established crested wheatgrass plantings as a bridging community to assist secondary succession toward a diverse community with significant components of native plants. They used herbicide and mechanical treatments to control crested wheatgrass and then used several seeding techniques to plant native grasses and shrubs into the prepared sites in 1998 (Table 1). The initial removal of crested wheatgrass in this trial opened an establishment window for the native plants, and within $2 \mathrm{y} \mathrm{a}$ thriving native grass (up to $10 / \mathrm{m}^{2}\left[0.93 / \mathrm{ft}^{2}\right]$ ) and native shrub (up to $5 / \mathrm{m}^{2}\left[0.46 / \mathrm{ft}^{2}\right]$ ) community was established (Cox and Anderson 2004). 


\section{TABLE 1}

List of species planted into treated crested wheatgrass plots, 1997-1999.

\section{Shrub species}

Big sagebrush (Artemisia tridentata Nutt. var. Asteraceae tridentata)

Fourwing saltbush (Atriplex canescens (Pursh) Chenopodiaceae Nutt.)

Rubber rabbitbrush (Ericameria nauseosa (Pall. ex Asteraceae Pursh) G.L. Nesom \& Baird)

\section{Grass species}

Bluebunch wheatgrass (Pseudoroegneria spicata Poaceae (Pursh) Á. Löve)

\begin{tabular}{ll}
\hline Galleta (Pleuraphis jamesii Torr.) & Poaceae \\
\hline $\begin{array}{l}\text { Needle and thread grass (Hesperostipa comata } \\
\text { (Trin. \& Rupr.) Barkworth) }\end{array}$ & Poaceae \\
\hline Sandberg bluegrass (Poa secunda J. Presl) & Poaceae \\
\hline Squirreltail (Elymus elymoides (Raf.) Swezey) & Poaceae \\
\hline
\end{tabular}

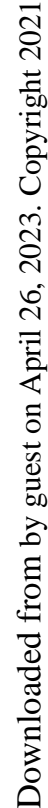

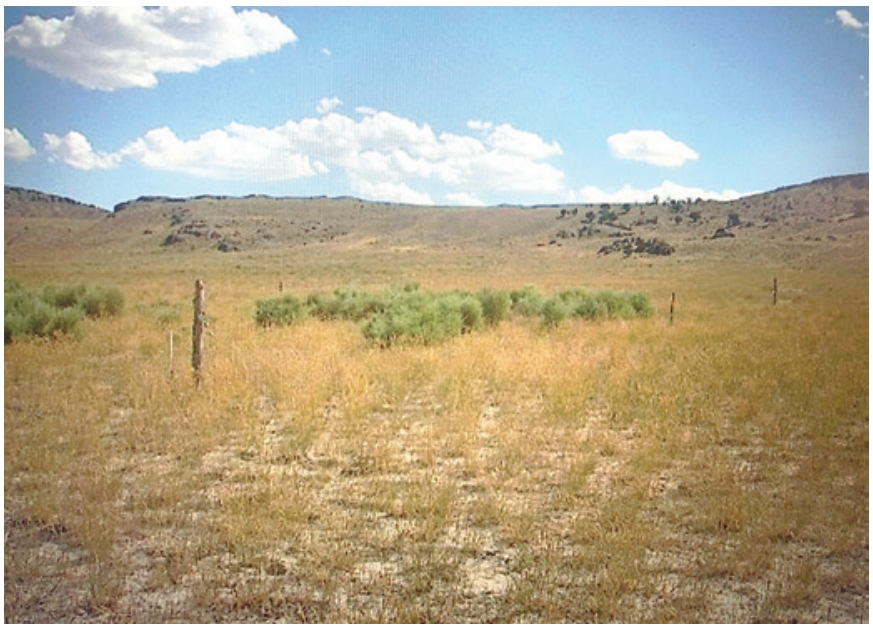

Figure 1. Crested wheatgrass 10-y post-planting.

A return visit to the crested wheatgrass sites 10 -y postplanting found that the native grasses while present, were greatly diminished in numbers, but there were still significant numbers of native shrubs with primarily an understory of the recovered crested wheatgrass (Figure 1).

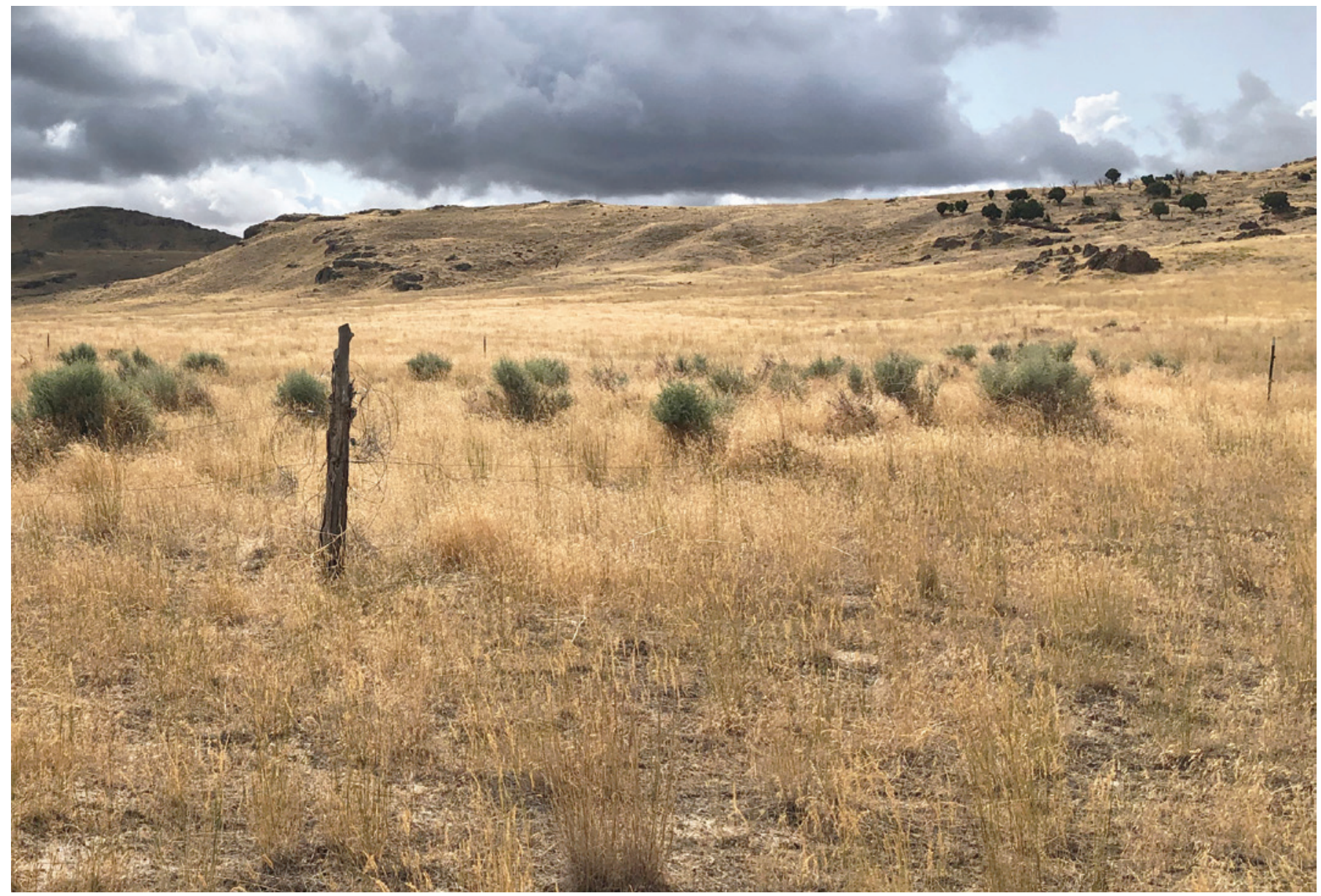


At roughly 20-y post-planting, the crested wheatgrass sites had severely degraded, both inside of the treated plots as well as outside. Crested wheatgrass was significantly reduced and many of the native shrubs had perished with remaining shrubs decadent. A few native grasses were still present, but extremely sparse. The big change was an invasion of cheatgrass into a crested wheatgrass-dominated community that had just $10 \mathrm{y}$ earlier been impervious to cheatgrass (Figure 2). In the course of $20 \mathrm{y}$ our experimental plots went from crested wheatgrass dominance to a native shrub and native grass mix, to a native shrub and crested wheatgrass mix, to a cheatgrass-dominated site with declining crested wheatgrass, native shrubs, and native grasses. So, the seeming success of 2-y post-treatment conversion of crested wheatgrass stands to a diverse native community ended unexpectedly in a less stable plant community dominated by cheatgrass in the space of $20 \mathrm{y}$.

The cause of the crested wheatgrass die-off is unknown but may have been affected during the somewhat common cheatgrass die-off events known to occur in this area and attributed to the fungal pathogen black fingers of death (Pyrenophora semeniperda (Brittleb. \& D. B. Adam) Shoemaker [Pleosporaceae]) (Boyte and others 2014) or by army cutworms (Euxoa auxiliaris Grote [Noctuidae]) (Salo 2018). While black fingers of death have been documented to cause mortality in cheatgrass and other native perennial grasses (Beckstead and others 2010), its effect on crested wheatgrass has not been studied. We have, however, observed crested wheatgrass mortality in greenstrips transecting cheatgrass die-off patches in this area.

Concurrent to the crested wheatgrass diversification study, a similar approach was taken to examine dry montane meadows in Ephraim Canyon dominated by smooth brome resulting from U.S. Forest Service seedings in 1947. Sites were selected and fenced prior to herbicide and tilling treatments in the early summer of 2002 to remove smooth brome. Native species of grasses, forbs, and shrubs were seeded into these sites later that fall (Table 2). Evaluation of the sites 2 y post-planting determined the seeding to be an absolute failure. Sites were densely covered by weedy annuals with no apparent success of seeded

\section{TABLE 2}

List of species planted into treated smooth brome plots.

\begin{tabular}{|c|c|c|c|}
\hline Shrub species & Family & Patches & Rows \\
\hline Bitterbrush (Purshia tridentata (Pursh) DC.) & Rosaceae & & $\mathrm{x}$ \\
\hline Silver sagebrush (Artemisia cana Pursh) & Asteraceae & & $x$ \\
\hline Vasey's sagebrush (Artemisia tridentata Nutt. var. vaseyana (Rydb.) B. Boivin) & Asteraceae & $x$ & \\
\hline \multicolumn{4}{|l|}{ Grass species } \\
\hline Alpine timothy (Phleum alpinum $\mathrm{L}$.) & Poaceae & & $x$ \\
\hline Bluebunch wheatgrass (Pseudoroegneria spicata (Pursh) Á. Löve) & Poaceae & $x$ & \\
\hline Canada wildrye (Elymus canadensis L.) & Poaceae & & $x$ \\
\hline Slender wheatgrass (Elymus trachycaulus (Link) Gould) & Poaceae & $x$ & \\
\hline Western wheatgrass (Pascopyrum smithii (Rydb.) Barkworth \& D.R. Dewey) & Poaceae & $x$ & \\
\hline \multicolumn{4}{|l|}{ Forbs } \\
\hline American vetch (Vicia americana Muhl. ex Willd.) & Fabaceae & & $x$ \\
\hline Arrowleaf balsamroot (Balsamorhiza sagittata (Pursh) Nutt.) & Asteraceae & & $\mathrm{x}$ \\
\hline Cinquefoil (Potentilla gracilis Douglas ex Hook.) & Asteraceae (Rosaceae) & & $\mathrm{x}$ \\
\hline Horse-nettle (Agastache urticifolia (Benth.) Kuntze) & Lamiaceae & & $x$ \\
\hline Jacob's ladder (Polemonium foliosissimum A. Gray) & Polemoniaceae & & $\mathrm{x}$ \\
\hline Louisiana wormwood (Artemisia ludoviciana Nutt.) & Asteraceae & $x$ & \\
\hline Rocky Mountain penstemon (Penstemon strictus Benth.) & $\begin{array}{l}\text { Plantaginaceae } \\
\quad \text { (Scrophulariaceae) }\end{array}$ & & $\mathrm{x}$ \\
\hline Showy goldeneye (Heliomeris multiflora Nutt.) & Asteraceae & $x$ & \\
\hline Silver lupine (Lupinus argenteus Pursh) & Fabaceae & & $\mathrm{x}$ \\
\hline Sticky geranium (Geranium viscosissimum Fisch. \& C.A. Mey.) & Geraniaceae & & $\mathrm{x}$ \\
\hline Western aster (Symphyotrichum ascendens (Lindl.) G.L. Nesom) & Asteraceae & $x$ & \\
\hline Western sweet-cicely (Osmorhiza occidentalis (Nutt. ex Torr. \& A. Gray) Torr.) & Apiaceae & & $x$ \\
\hline Yarrow (Achillea millefolium L.) & Asteraceae & $x$ & \\
\hline
\end{tabular}




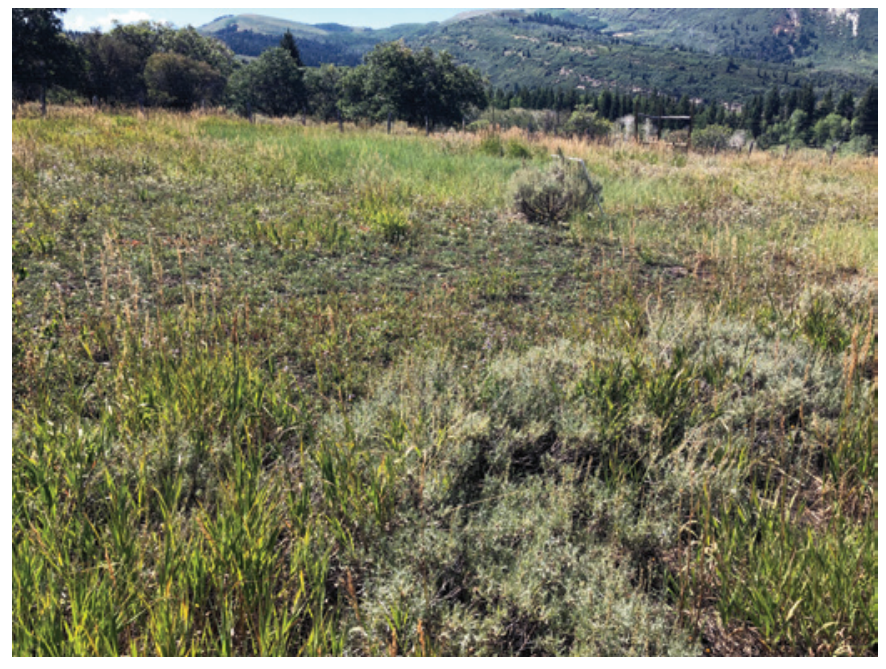

Figure 3. 20-y post-treatment showing the site dominated by native plant diversity with a subordinate smooth brome component.

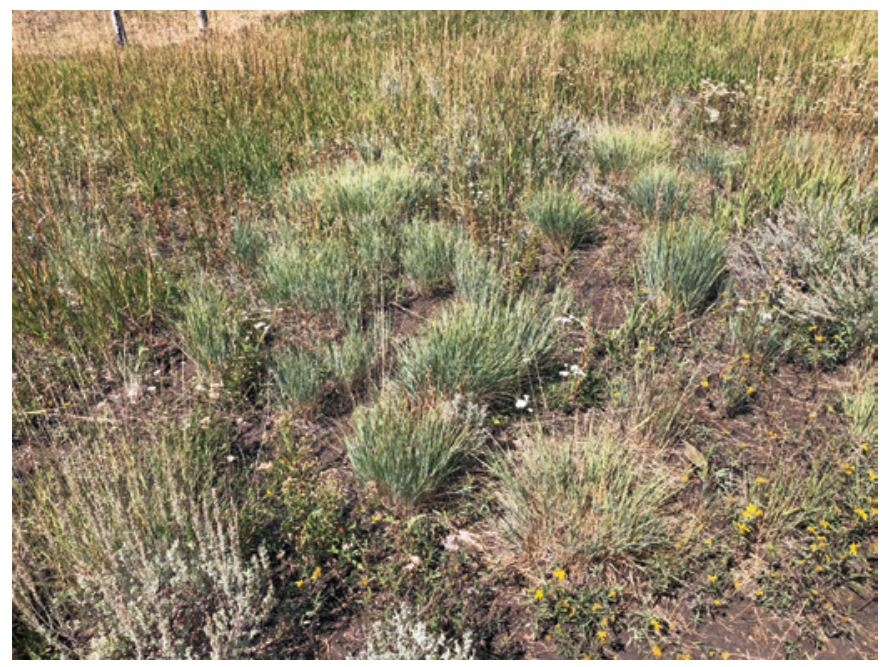

Figure 4. Smooth brome site $20-y$ post-planting. Bluebunch wheatgrass representing species that established in discreet patches.

species. The study sites were abandoned, though fences were maintained for potential further use of the enclosed plots.

A 10 -y post-planting visit to the smooth brome sites revealed that a few of the native species were present and annual weeds still dominated these sites. At a 20 -y post-planting visit to the smooth brome sites, we found a great surprise. A high percentage of the native species that were seeded including grasses, forbs, and shrubs were present in a very diverse plant community. Smooth brome had returned into the seeded areas, but it was far from dominant (Figure 3). The native species had niche separated with some spreading in patches across the seeded areas (Figure 4), whereas others seemed to be constrained to the rows in which they were planted (Figure 5).

Perhaps the most unexpected element of the community was the presence of bare ground interspaces between established native plants (Figure 6). In a native, montane, dry

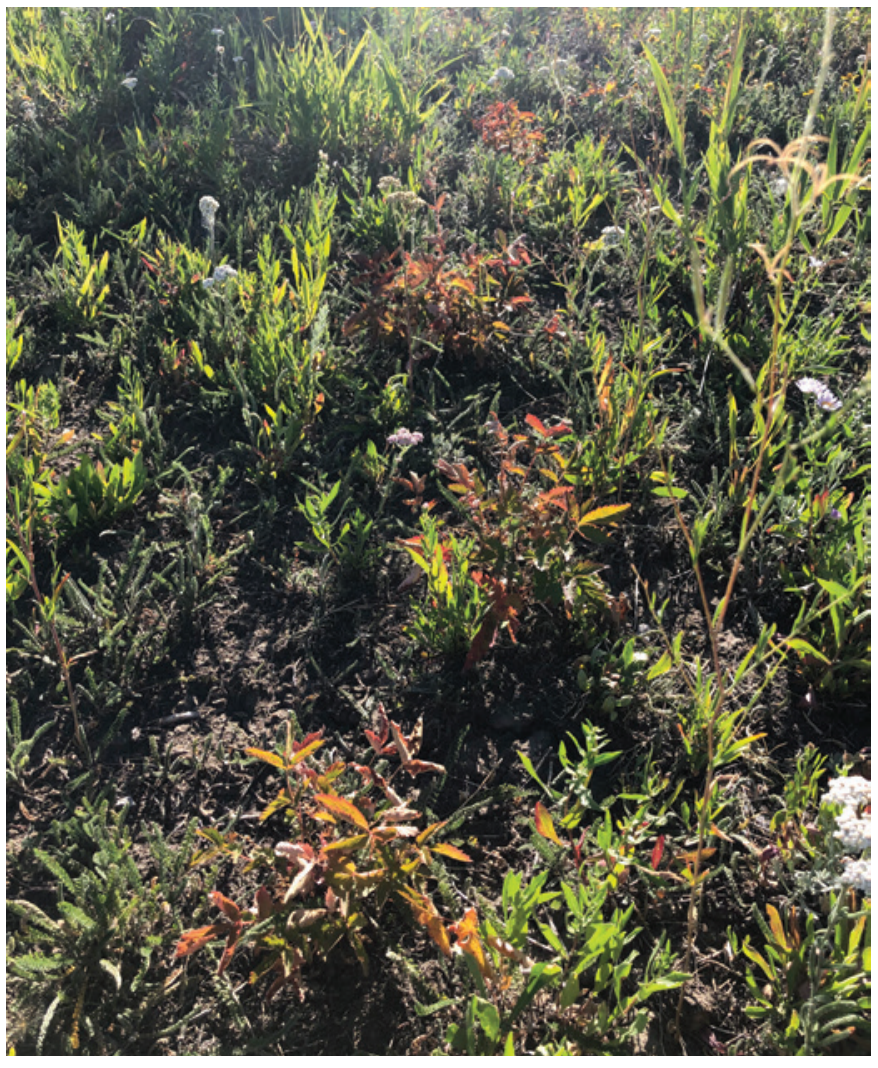

Figure 5. Smooth brome site 20-y post-planting. Cinquefoil representing species that remained restricted to planting rows.

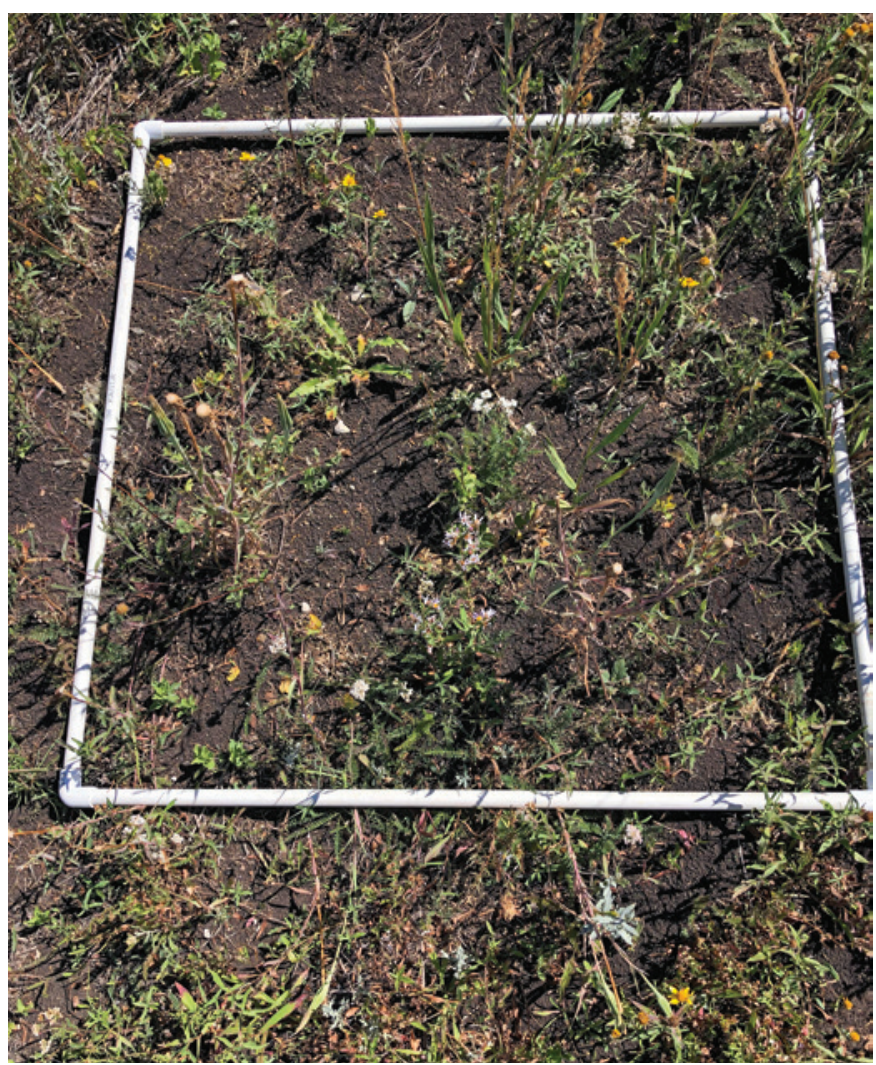

Figure 6. Native species dominating site with bare ground interspaces. 


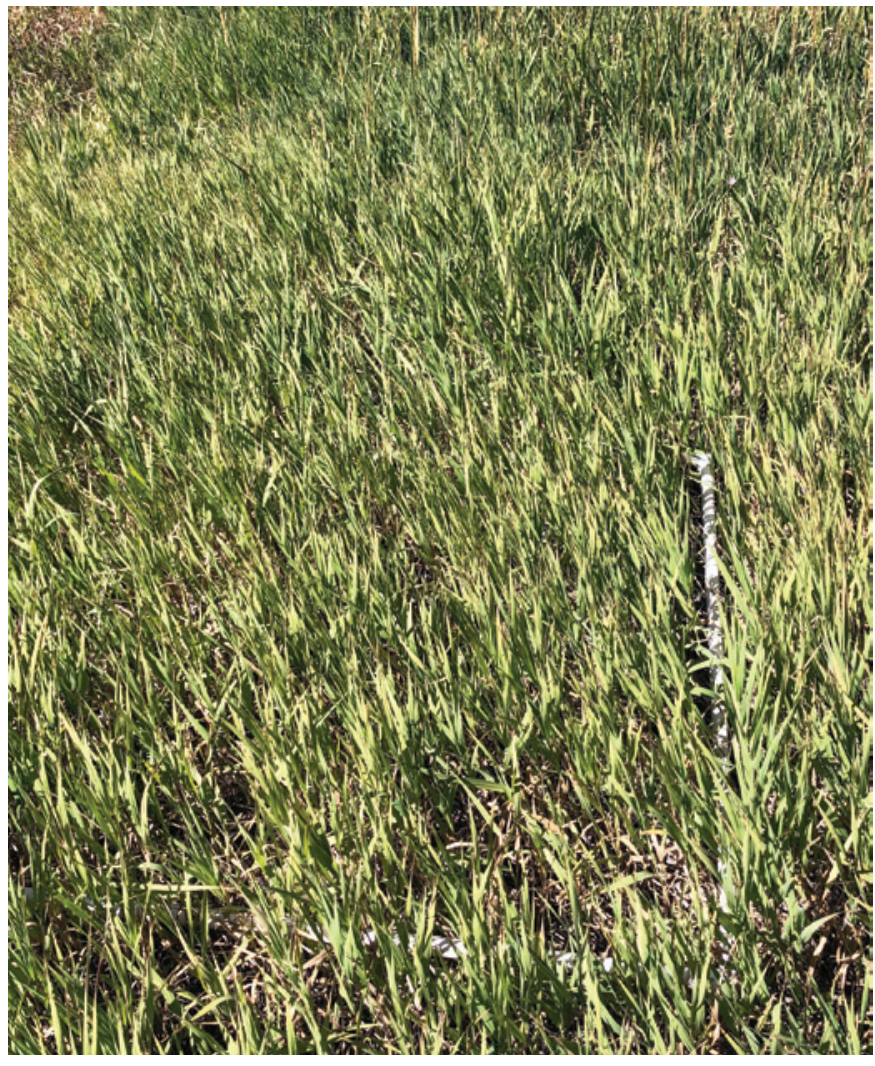

Figure 7 . Original condition of the sod-forming smooth brome site with $100 \%$ cover (no bare ground).

meadow, a component of bare ground would be expected; however, with the takeover and dominance of smooth brome, bare ground had disappeared as it was occupied by the rhizomatous grass (Figure 7). Even though smooth brome was conspicuously present throughout the seeded areas, and pure stands surrounded the seeded plots, it was intriguing that the native species were able to not only occupy the site but also hold off the advances of smooth brome and maintain approximately $15 \%$ bare ground interspaces. So, in the space of $20 \mathrm{y}$, these sites, in contrast to the crested wheatgrass sites, went from smooth brome dominance to a failed native seeding resulting in a weedy patch, to an emerging native community dominated by weeds, to a diverse native plant community with cover estimates by life form consisting of $10 \%$ shrub, $20 \%$ native grass, $35 \%$ native forb, and $20 \%$ smooth brome held in a subordinate role. On these sites, a question remains as to whether this community is sustainable when the $2.5 \mathrm{~m} \mathrm{(8 \textrm {ft } )}$ fence is removed and this community is subjected to wild ungulate and permitted livestock use (Figure 8).

\section{DISCUSSION}

Our attempt to reintroduce native plant diversity into crested wheatgrass-dominated stands had immediate positive results. Subsequent perturbations, which we attribute to drought and

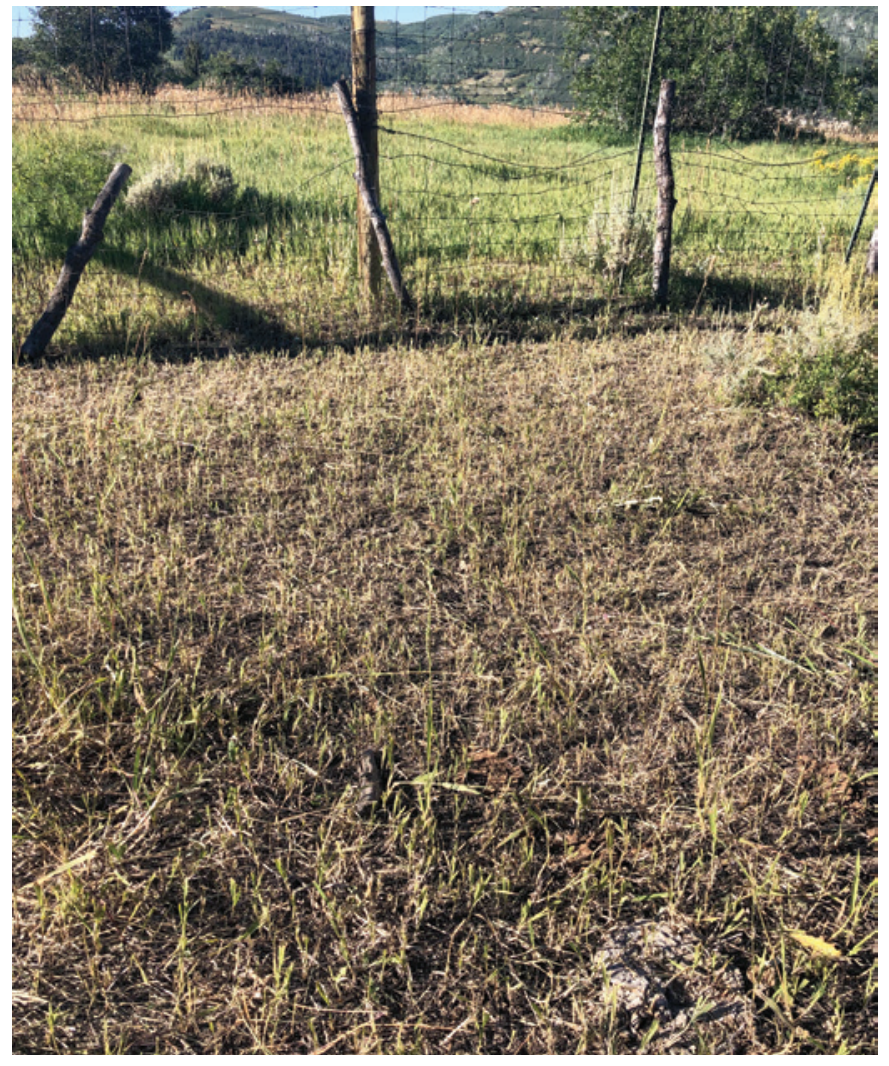

Figure 8 . Evidence of the intense grazing by wildlife and cattle outside the exclosure, a perturbation that favors smooth brome.

grass die-off events, exceeded the restored community's ability to survive and recover. Shrubs, primarily fourwing saltbush (Atriplex canescens (Pursh) Nutt. [Chenopodiaceae]) and rubber rabbitbrush (Ericameria nauseosa (Pall. ex Pursh) G.L. Nesom \& Baird [Asteraceae]), did persist but are also vulnerable to extirpation due to the fine fuel load of re-invading cheatgrass and its associated fire risk. This finding suggests that the restored plant community was and is highly unstable under extant perturbations, a shared phenomenon with other arid native plant communities in the West.

Contemporary restoration ideals favor the re-establishment of the historic reference community; however, the current and projected severity and frequency of disturbances such as fire, drought, and weed invasion are outside of the evolutionary forces in which the historic plant reference community evolved. Even if it were possible, simply restoring land back to native plant communities will invariably restore the same high vulnerability and instability already observed in existing arid native plant communities under current management practices. The goal of increased stability through increased diversity will not be realized without introducing the functional contribution of plants that can endure drought, resist and recover from fire, sustain grazing, and outcompete invasive weeds. This path will require the acceptance of novel plant communities as the archetype for restoration goals moving forward. For many it 
will be a difficult pill to swallow but perhaps the only medicine that can save a part of the whole.

Conversely, the results of seeding native species into treated smooth brome meadows took several decades to fully manifest. During this time the reseeded sites were protected from wild ungulate and cattle grazing, and the impact of reintroducing grazing may favor the return of smooth brome dominance. The fate of these restoration plantings may ultimately suffer the same fate as the crested wheatgrass plantings where current perturbations favor an unpreferred result, in this case a smooth brome monoculture. A key element to assess when defining restoration goals, and ultimately what to include in a seed mix, is the type and severity of disturbances expected to occur. When present, perturbations are generally the driving force behind plant community composition, not just the composition of the seed mix. On sites experiencing little or no disruption, the desired plant composition can influence what to plant as long as stresses from future impacts do not have significant departure from evolutionary pressures.

The fact remains that many of these non-native, perennial grass-dominated communities continue to provide the original desired function of soil stabilization, weed suppression, and improved forage, despite a lack of plant diversity. Land managers must consider the cost or benefits to increasing native plant diversity. A goal to remedy a lack of plant diversity will require either community replacement at one extreme or species augmentation at the other. The resources required to replace an established community of crested wheatgrass or smooth brome is significant, and the required disturbance puts a site at risk to the very things the non-native grasses were planted to prevent. A species augmentation approach therefore has less risk and a greater potential for success if we can accept that one of the outcomes will be the continued presence of the introduced perennial grass in the community. Coincidentally, the diversity-stability theory does not exclude non-native species as long as they contribute to a positive functional diversity.

\section{CONCLUSION}

While scientists strive to measure the relationship between organism diversity and ecosystem health and stability, land managers face the challenge of how to best restore or improve degraded plant communities. Reseeding following wildfire, especially in environments with low precipitation and where risk of weed invasion is high, continues to be the common practice.

Given a seeming success turned failure (crested wheatgrass sites) and a seeming failure turned success (smooth brome sites), the questions asked earlier still need to be addressed. Even if we can convert these monospecific stands of planted, introduced species, should we do it, and at what cost and risk?
The diversification of monospecific, introduced grass stands will be expensive in the effort, and failed attempts may well put these lands back in ecological jeopardy. These introduced grasses have become naturalized in our ecosystems and cannot realistically be extirpated from these sites. The success they have historically had in arresting erosion and providing high quality, grazing resistant forage cannot be ignored. Because of apparent changes in climate patterns and rampant wildfires consuming ever more land, our highest priority needs to move toward stabilization of newly compromised lands. We applaud and even participate in the extensive efforts being made to enhance the breadth and performance of native species; however, wide-scale reseeding success using native species has not rivaled the success of earlier plantings using introduced species. Historical degradation coupled with changes in land use, climate, invasive weeds, fire ecology, and so forth may force us to re-evaluate the current popular mindset that we should and can return our ecosystems back to pre-European compositions and function. Instead, functional diversity may have to be achieved using novel plant communities composed of species that can establish and achieve ecological functionality regardless of origin.

One important lesson-learned from both case study planting trials-is the need to monitor plots for many years. Usually, academic research focuses on projects that yield results within the timeframe required for a student to graduate with a master's or a doctoral degree, 2 to $4 \mathrm{y}$. To fully understand the research outcomes of restoration projects, several decades may be required as observed in the 2 case studies we present here.

\section{REFERENCES}

Beckstead J, Meyer SE, Connolly BM, Huck MB, Street LE. 2010. Cheatgrass facilitates spillover of a seed bank pathogen onto native grass species. Journal of Ecology 98:168-177.

Boyte SP, Wylie BK, Major DJ. 2014. Mapping and monitoring cheatgrass die-off in rangelands of the Northern Great Basin, USA. Rangeland Ecology and Management 68:18-28.

Connor LG. 1921. A brief history of the sheep industry in the United States. Agricultural History Society Papers. Volume 1. $107 \mathrm{p}$.

Cox RD, Anderson VJ. 2004. Increasing native diversity of cheatgrassdominated rangeland through assisted succession. Journal of Range Management 57:203-210.

De Groot RS. 1992. Functions of nature: evaluation of nature in environmental planning, management and decision making. Groningen, The Netherlands: Wolters-Noordhoff. 315 p.

De Groot RS, Wilson MA, Boumans RMJ. 2002. A typology for the classification, description and valuation of ecosystem functions, goods and services. Ecological Economics 41:393-408.

Holechek JL, Pieper RD, Herbel CH. 2004. Range management: principles and practices. 5th ed. Upper Saddle River (NJ): Pearson/ Prentice Hall. 607 p.

Johnson KL. 1989. Rangeland resources of Utah. Logan (UT): Cooperative Extension Service, Utah State University. 103 p. 
Keck WM. 1972. Great Basin Station-sixty years of progress in range and watershed research. USDA Forest Service Research Paper INT118. $40 \mathrm{p}$.

Larson DL, Anderson PJ, Newton N. 2001. Alien plant invasion in mixed-grass prairie: effects of vegetation type and anthropogenic disturbance. Ecological Applications 11(1):128-141.

Pasari TL, Zavaleta ES, Tilman D. 2013. Several scales of biodiversity affect ecosystem functionality. Proceedings of the National Academy of Sciences of the United States of America (PNAS) 110:1021910222.

Pellant MP, Shaver P, Pyke DA, Herrick JF. 2005. Interpreting indicators of rangeland health, version 4. Denver (CO): U.S. Department of the Interior, Bureau of Land Management, National Science and Technology Center. BLM/WO/ST-00/001+1734/REV05. Technical Reference 1734-6. $122 \mathrm{p}$.

Petchey OL, Gaston KJ. 2006. Functional diversity: back to basics and looking forward. Ecological Letters 9:741-758.

Pickford GD, Jackman ER. 1944. Reseeding Oregon summer ranges. Corvallis (OR): Oregon State Agricultural Experiment Station Circular $159.48 \mathrm{p}$.

Pratt PP. 1849. Letter from Parley P. Pratt to Orson Pratt, July 1849. Millennial Star 11:342

Salo C. 2018. Army cutworm outbreak produced cheatgrass die-offs and defoliated shrubs in Southwest Idaho in 2014. Rangelands 40:99-105.

Tilman D. 2001. Functional diversity. In: Levin SA, editor. Encyclopedia of biodiversity. San Diego (CA): Academic Press. p 109-120.

Tilman D, Downing JA. 1994. Biodiversity and stability in grasslands. Nature 367:363-365.
Tilman D, Knops J, Wedin D, Reich P, Ritchie M, Siemann E. 1997. The influence of functional diversity and composition on ecosystem processes. Science 277:1300-1302.

Tropicos.org. 2020. Online database. URL: http://www.tropicos.org (accessed 12 Feb 2020). St Louis (MO): Missouri Botanical Garden.

\section{AUTHOR INFORMATION}

\section{Val Jo Anderson}

Professor

Department of Plant and Wildlife Sciences

Brigham Young University

Provo, UT 84062

Val_Anderson@byu.edu

\section{Robert L Johnson}

Research Professor

Stanley L Welsh Herbarium

Monte L Bean Museum

Department of Biology

Brigham Young University

Provo, UT 84062

robert_johnson@byu.edu

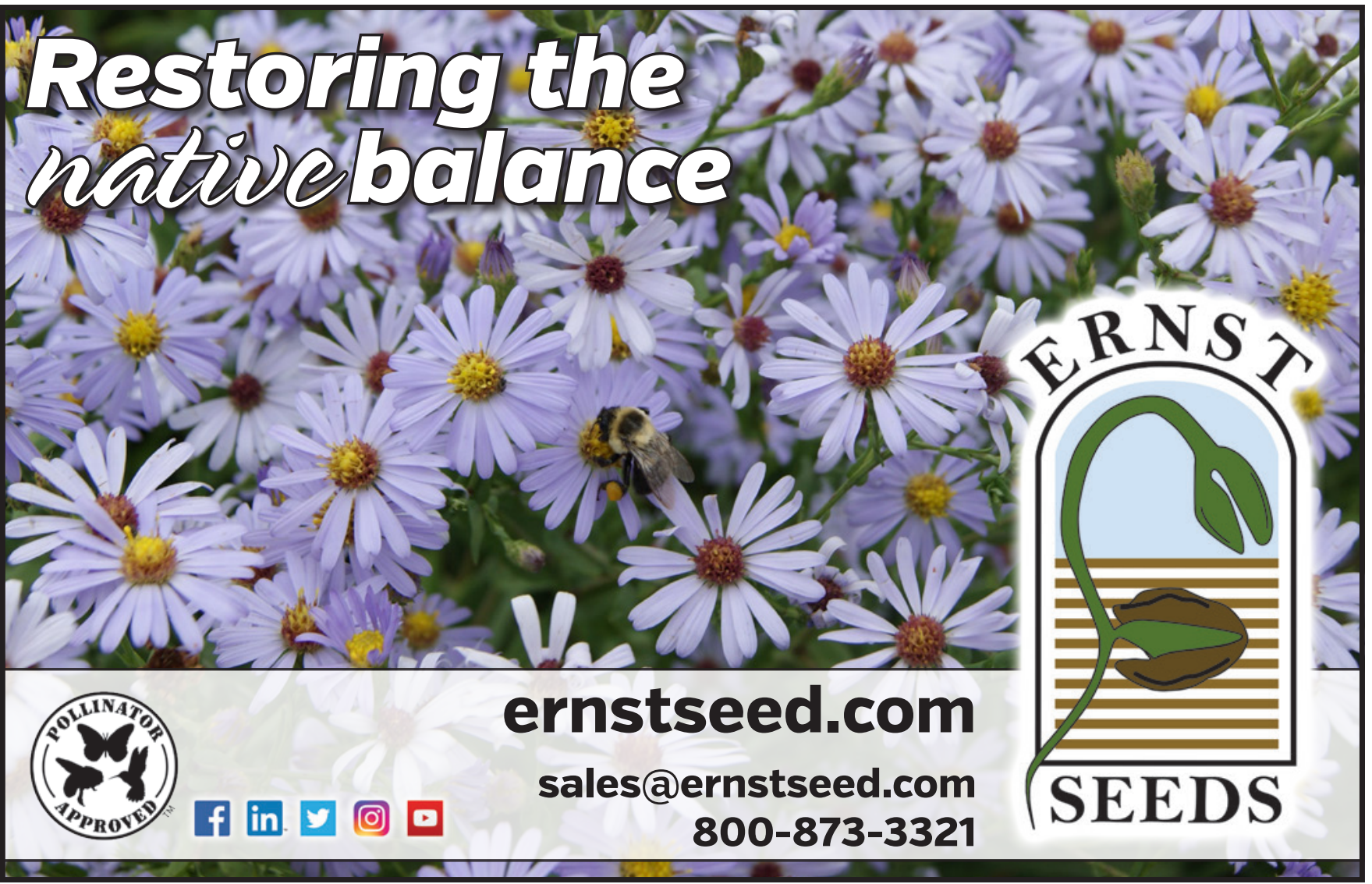

